\title{
KESADARAN SANTRI PONDOK PESANTREN AL-AQOBAH DALAM MENERAPKAN PROTOKOL KESEHATAN DI MASA PANDEMI COVID-19
}

\author{
Arizki Dwi Prasetyo ${ }^{1}$, Agus Machfud Fauzi ${ }^{2}$ \\ ${ }^{1}$ Mahasiswa, Universitas Negeri Surabaya, Jawa Timur, Indonesia \\ ${ }^{2}$ Dosen, Universitas Negeri Surabaya, Jawa Timur, Indonesia \\ e-mail: arizki.18040@mhs.unesa.ac.id, agusmfauzi@unesa.ac.id
}

\begin{abstract}
Abstrak
Sejak pandemi covid-19 kegiatan masyarakat menjadi lumpuh, termasuk juga kegiatan pembelajaran di Pondok Pesantren Al-Aqobah Jombang. Sejak bulan agustus 2020 kegiatan pembelajaran berjalan kembali namun dengan menerapkan prosedur protokol kesehatan yang sesuai dengan arahan pemerintah. Penerapan protokol kesehatan tidak dapat berjalan tanpa adanya kesadaran dari masing-masing individu yang menjalankan kegiatan. Penelitian ini bermaksud untuk mengetahui bagaimana kesadaran santri saat menjalankan kegiatan pembelajaran pesantren di masa pandemi. Metode penelitian yang digunakan ialah kualitatif, dengan melakukan wawancara pada santri pondok pesantren al-aqobah yang menjalankan kegiatan pembelajaran di masa pandemi. Penelitian ini menggunakan perspektif teori interaksi simbolik blumer. Hasil dari penelitian ini yaitu kegiatan pembelajaran yang dilaksanakan di masa pandemi wajib menggunakan masker dan mencuci tangan sebelum masuk. Jika ada santri yang tidak menggunakan masker pihak yayasan tidak mengizinkan untuk mengikuti kegiatan pembelajaran. Dalam hal ini, kesadaran para jamaah dalam menerapkan protokol kesehatan di masa pandemi terbentuk karena tiga faktor yaitu, pertama peraturan pihak pemerintah maupun pengurus pondok pesantren, kedua sosialisasi yang rutin diberikan, ketiga dorongan dari orang tua dan masyarakat sekitar. Selain menerapkan protokol kesehatan, santri juga memahami apa yang dimaksud dengan protokol kesehatan serta cara penerapan yang baik dan benar agar terhindar dari virus covid-19.
\end{abstract}

Kata Kunci: Kesadaran, Protokol Kesehatan, Santri

\section{PENDAHULUAN}

Setiap individu memiliki pandangan yang berbeda terhadap realitas sosial yang ada. Hal itu berlaku juga pada ketaatan individu dalam sebuah peraturan yang ditetapkan. Penerapan protokol kesehatan selalu menjadi perhatian utama selama masa pandemi dengan tujuan memutus rantai persebaran covid-19. Ketaatan individu pada peraturan belum tentu berasal dari dalam dirinya sendiri, bisa saja ada faktor lain yang membuat dirinya menjadi patuh pada peraturan yang ditetapkan.

Pandemi Covid-19 merubah keadaan yang biasanya masyarakat beraktivitas dengan bebas namun sejak pandemi menjadi terbatas untuk meminimalisir penyebaran virus tersebut. Hal ini berdampak pada segala sektor kehidupan seperti, ekonomi, sosial, politik, dan kesejahteraan masyarakat. Himbauan dari pemerintah agar pandemi Covid-19 ini dapat terselesaikan, 
Arizki Dwi Prasetyo, Kesadaran Santri Pondok Pesantren Al-Aqobah Dalam Menerapkan Protokol Kesehatan di Masa Pandemi Covid-19

masyarakat diminta untuk tetap berada di rumah. Namun, jika masyarakat akan beraktivitas di luar rumah, pemerintah mewajibkan untuk selalu menerapkan protokol kesehatan, seperti menggunakan masker, mencuci tangan, dan jaga jarak. ${ }^{1}$ Dalam kenyataannya, masih banyak masyarakat yang tidak patuh pada peraturan pemerintah. Padahal, kepatuhan akan peraturan tersebut sangat dibutuhkan untuk kepentingan bersama, dan pandemi yang dihadapi dapat segera terselesaikan.

Kepatuhan seseorang akan peraturan dapat dilihat dari kesadaran dirinya. Bagaimana ia sadar dan melakukan tindakan mengikuti peraturan yang telah di tetapkan. Kesadaran diri adalah tingkat dimana seseorang memperhatikan secara khas dirinya sendiri. Seseorang memahami dan secara sadar melakukan tindakan atas yang dikendaki dirinya. Ketika kesadaran diri tidak dimiliki oleh seseorang, sikap ketidakpedulian terhadap sekitar menjadi tinggi. Dalam hal ini, kesadaran diri seseorang terbagi atas dua bagian, yaitu kesadaran publik dan kesadaran internal. ${ }^{2}$ Kesadaran publik diukur atas tindakan orang lain pada dirinya, saat orang lain berfikir tentang dirinya. Ia berfikir bahwa dirinya menjadi objek, dan menimbulkan pemikiran atas dirinya sendiri sehingga ia menjadi sadar akan suatu hal. Sedangkan kesadaran internal hanya dapat dirasakan oleh orang itu sendiri. Kesadaran ini muncul atas beberapa tindakan dalam diri yang memperhatikan perasaan batin nya, seperti kesadaran akan sikap, tindakan, pikiran, perasaan, dan lain - lain.

Penelitian sebelumnya dilakukan oleh Deby Zulkarnain Rahadian Syah, Dewi Utari, dan Tetra Saktika Adinugraha dengan judul penelitian "Edukasi Penerapan Protokol Kesehatan Penyelenggaraan Kegiatan Baca Tulis Al-Quran Pada Masa Pandemi Covid-19 di TPQ Masjid Awalulmu'minin Gamping" yang menghasilkan kegiatan TPQ telah dilaksanakan sejak bulan juli namun protokol kesehatan yang dijalankan hanya mencuci tangan. Kegiatan dalam seminggu hanya tiga kali pertemuan yaitu hari senin, selasa, dan rabu. Pada awal sebelum masuk sudah diinfokan untuk melakukan physical distancing, karena santri yang merupakan anak-anak maka masih sulit untuk menerapkan protokol sesuai covid-19. Edukasi protokol kesehatan diberikan agar santri, guru, dan pengurus dapat menerapkan protokol kesehatan yang sesuai. Proses penyampaian materi edukasi melalui LCD proyektor selama 15 menit, dengan memberikan waktu untuk diskusi. Ada lima protokol kesehatan pencegahan covid-19 yang disampaikan yaitu, mengenakan masker wajah, dalam keadaan sehat, menjaga kebersihan tangan, jaga jarak minimal 1 meter, dan menghindari kontak fisik. Setelah tiga hari melakukan edukasi, santri dapat

${ }^{1}$ F. C. Farisa, "Presiden Jokowi: Saat Ini Semua Wajib Pakai Masker," Kompas.com, 2021. https://nasional.kompas.com/read/2021/07/19/05312271/presiden-jokowi-saat-ini-semua-wajib-pakaimasker.

${ }^{2}$ Froming, W. J., \& Carver, C. S. (1981). Divergent influences of private and public selfconsciousness in a compliance paradigm. Journal of Research in Personality, 15(2), 159-171. https://doi.org/10.1016/0092-6566(81)90015-5

Al Qalam: Jurnal Ilmiah Keagamaan dan Kemasyarakatan Vol. 16, No. 1 Januari - Juni 2022 
Arizki Dwi Prasetyo, Kesadaran Santri Pondok Pesantren Al-Aqobah Dalam Menerapkan Protokol Kesehatan di Masa Pandemi Covid-19

menerapkan protokol kesehatan sesuai yang telah disampaikan. Santri dan guru mengenakan masker dan mencuci tangan dengan bersih. ${ }^{3}$

Penelitian terdahulu yang kedua oleh Arif Bagas Adi Saputra yang berjudul "Pelaksanaan Ibadah Sholat Berjamaah Dalam Masa Pandemi Covid-19 di Kelurahan Kalicacing Kecamatan Sidomukti Kota Salatiga Tahun 2020". Hasil dari penelitian ini adalah pelaksanaan ibadah sholat berjamaah di masa pandemi berjalan dengan aman dan lancar, hal itu dibarengi dengan patuhnya masyarakat dalam menerapkan protokol kesehatan. Jarak shaf shalat dibuat renggang dengan memberikan tanda silang atau himbauan atas dasar kesadaran masing-masing jamaah. Pandemi Covid-19 tidak memiliki pengaruh dalam kekhusyukan melaksanakan sholat berjamaah. Dalam hal ini, masyarakat memiliki beragam persepsi tentang sholat berjamaah dimasa pandemi seperti, beberapa jamaah merasa aman melaksanakan sholat berjamaah karena menerapkan protokol kesehatan, ada jamaah yang merasa khawatir dalam melaksanakan ibadah di masjid di masa pandemi Covid-19, dalam aturan masjid ibadah dilaksanakan dengan berjarak dan renggang serta menerapkan protokol kesehatan, ada yang merasa aman dan nyaman melaksanakan ibadah dimasa pandemi dengan menerapkan protokol kesehatan namun ada juga yang merasa tidak nyaman menerapkan protokol kesehatan karena dinilai terlalu rumit padahal padahal hanya untuk beribadah, terkait kekhusyukan ibadah jamaah menilai tidak ada pengaruh masa pandemi dalam kekhusyukan sholat semua itu tergantung pada diri masing-masing, akan tetapi ada beberapa jamaah yang merasa was-was karena ada orang luar yang ikut ibadah dalam jamaah tersebut, dan seluruh jamaah merasa tidak ada gejolak yang mempengaruhi ibadah di masa pandemi di Kelurahan Kalicacing Kecamatan Sidomukti Kota Salatiga. ${ }^{4}$

Penelitian terdahulu yang ketiga dilakukan oleh Kinten Nafa Aulia dengan judul penelitian "Meningkatkan Kesadaran Masyarakat Untuk Memperhatikan Prokes (Protokol Kesehatan) Dalam Beraktifitan di Era NeNo (New Normal) dengan Media PEPC (Poster Edukasi Pencegahan Covid-19) Melalui Media Wafagram (WA, Facebook, dan Instagram) di Kampung Padang Laban, Nagari Pasia Pelangai, Kecamatan Ranah Pesisir, Kabupaten Pesisir Selatan". Dari hasil penelitian memperoleh data bahwa meningkatkan kesadaran masyarakat dengan media poster yang disebar melalui Wafagram (WA, Facebook, dan Instagram) berdampak cukup signifikan, yang mana sebelumnya hanya sekitar 46\% masyarakat Padang Laban yang memahami protokol kesehatan. Pasca melakukan evaluasi pemahaman masyarakat tentang protokol

${ }^{3}$ Syah, D. Z. R., Utari, D., \& ... (2020). Edukasi penerapan protokol kesehatan penyelenggaraan kegiatan pada masa pandemi Covid 19 Di TPQ Masjid Awalulmu’Minin. Jurnal Pengabdian ..., 2(2), 2833. http://jurnal.poltekkeskhjogja.ac.id/index.php/jpmkh/article/view/408

${ }^{4}$ Satria, A. B. A. (2020). Pelaksanaan Ibadah Salat Berjamaah Dalam Masa Pandemi Covid-19 Di Kelurahan Kalicacing Kecamatan Sidomukti Kota Salatiga Tahun 2020. 9.

Al Qalam: Jurnal Ilmiah Keagamaan dan Kemasyarakatan Vol. 16, No. 1 Januari - Juni 2022 
Arizki Dwi Prasetyo, Kesadaran Santri Pondok Pesantren Al-Aqobah Dalam Menerapkan Protokol Kesehatan di Masa Pandemi Covid-19

kesehatan meningkat menjadi $91 \%$, dan terdapat $95 \%$ masyarakat yang memahami pentingnya menerapkan protokol kesehatan di era new normal. Artinya, dari 20 orang sekitar 18 orang memahami dengan baik terkait informasi yang telah diberikan. Selain itu, masyarakat juga memberikan respon yang positif dengan menggunakan metode seperti ini, artinya metode ini cukup efektif untuk meningkatkan pemahaman masyarakat. ${ }^{5}$

Kesadaran diri yang kurang menjadi salah satu faktor tidak taat nya seseorang menjalankan aturan. Hal ini terjadi karena tidak adanya dorongan kesadaran diri untuk bertindak sesuai apa yang di tetapkan. Namun, banyak orang yang bertindak hanya mengikuti kemauan diri sendiri tanpa mempertimbangkan dampak yang ditimbulkan pada orang lain. Penularan virus yang begitu cepat dan tidak terlihat oleh mata membuat semua orang harus lebih waspada. Tingkat kewaspadaan tersebut masih belum tertanam dalam diri semua orang, masih saja ada orang yang mengesampingkan protokol kesehatan yang telah ditetapkan. Sehingga, menjadi lebih sulit untuk mengurangi angka penyebaran. Melawan covid-19 tidak dapat dilakukan tanpa adanya kerjasama dari semua orang, karena harus ada kesadaran dalam diri setiap orang untuk memutus mata rantai penyebaran. Pandemi tidak dapat berakhir jika kesadaran masyarakat masih kurang. Orang yang memiliki kesadaran diri tinggi akan bertindak sesuai apa yang di harapkan oleh masyarakat, bagaimana ia dipandang oleh masyarakat, dan tidak membuat resah masyarakat di sekitarnya. ${ }^{6}$

\section{METODE PENELITIAN}

Penelitian Kesadaran Santri Pondok Pesantren Al-Aqobah Dalam Menerapkan Protokol Kesehatan di Masa Pandemi Covid-19 ini menggunakan penelitian kualitatif. Pengumpulan data yang digunakan dengan melakukan wawancara pada jamaah masjid yang melaksanakan kegiatan masjid selama masa pandemi kemudian menjelaskan hasil dalam bentuk deskriptif. Teknik pengumpulan data menggunakan wawancara dan studi pustaka. Wawancara dilakukan secara online dari rumah masing-masing melalui media online yang dapat digunakan seperti whatsapp. Dalam penelitian ini, data yang digunakan berupa hasil wawancara pada informan dan jurnal terkait. Selain menggunakan data primer, peneliti juga menggunakan data sekunder yang berasal

5 Aulia, K. N. (2020). Meningkatkan Kesadaran Masyarakat Untuk Memperhatikan Prokes (Protokol Kesehatan) Dalam Beraktifitan di Era NeNo (New Normal) dengan Media PEPC (Poster Edukasi Pencegahan Covid-19) Melalui Media Wafagram (WA, Facebook, dan Instagram) di Kampung Padang Lab. Universitas Negeri Padang, 1-23.

${ }^{6}$ Huang, Y. W., Lin, P. C., \& Wang, J. (2018). The influence of bus and taxi drivers' public selfconsciousness and social anxiety on aberrant driving behaviors. Accident Analysis and Prevention, 117(May 2017), 145-153. https://doi.org/10.1016/j.aap.2018.04.014

Al Qalam: Jurnal Ilmiah Keagamaan dan Kemasyarakatan Vol. 16, No. 1 Januari - Juni 2022 
Arizki Dwi Prasetyo, Kesadaran Santri Pondok Pesantren Al-Aqobah Dalam Menerapkan Protokol Kesehatan di Masa Pandemi Covid-19

dari jurnal penelitian terdahulu yang digunakan serta literatur-literatur lain yang berkaitan dengan topik penelitian.

Penelitian ini menggunakan metode kualitatif dengan menggunakan pendekatan fenomenologi. Pendekatan fenomenologi diambil karena peneliti menginginkan sebuah data yang bersumber dari kehidupan asli informan. Selain itu, data yang didapatkan dengan menggunakan pendekatan fenomenologi ialah berasal dari pengalaman pribadi informan, maka dari itu kesesuaian data yang akan diperoleh sangat valid. Pendekatan ini diarahkan langsung pada pemikiran informan yang objektif dalam menyikapi pengalaman hidupnya atau fenomena yang telah mereka alami. Penelitian yang ada akan mengambil sebuah teori Interaksi Simbolik dari Blumer yang menjelaskan bahwa setiap individu saling menerjemahkan dan mendefinisikan tindakannya. Hal itu bukan hanya sekedar reaksi belaka, namun atas dasar "makna" yang diberikan terhadap tindakan orang lain. Interaksi antar individu diantarai oleh penggunaan simbolsimbol, interpretasi, berusaha saling memahami maksud dari tindakan masing-masing individu. Pada teori ini merangkan bahwa tindakan manusia tidak disebabkan oleh "kekuatan luar" sebagaimana yang dimaksud pengaruh orang lain, dan tidak juga disebabkan oleh "kekuatan dalam" sebagaimana yang dimaksud dipengaruhi jiwa sendiri, akan tetapi didasarkan pada pemaknaan atas sesuatu yang dihadapinya melalui proses yang disebut Blumer Self-Indication. Menurut Blumer self-indication adalah proses komunikasi pada diri individu dimulai dari mengetahui sesuatu, menilai, memberi makna, dan mengambil keputusan bertindak sesuai makna tersebut. ${ }^{7}$ Penelitian ini menunjukkan kesadaran santri pondok pesantren dalam menerapkan protokol kesehatan. Kesadaran tersebut bukan berasal dari dirinya, namun muncul karena adanya dorongan serta paksanaan dari pihak yayasan yang memberlakukan peraturan wajib protokol kesehatan.

\section{HASIL DAN PEMBAHASAN}

Hasil dari penggalian data primer oleh peneliti ditemukan beberapa hal mengenai Kesadaran Santri Pondok Pesantren Al-Aqobah Jombang Dalam Menerapkan Protokol Kesehatan Pada Masa Pandemi Covid-19.

Informan yang dituju ada lima orang dengan kriteria yang telah ditentukan sebelumnya di metode penelitian. Kelima informan tersebut merupakan santri pondok pesantren Al-Aqobah yang menjalankan aktivitas diniyah di masa pandemi, baik yang menerapkan protokol kesehatan maupun jarang menerapkan protokol kesehatan.

${ }^{7}$ D. Ahmadi, "INTERAKSI SIMBOLIK: SUATU PENGANTAR," Terakreditasi Dirjen Dikti SK No. 56/DIKTI/Kep/2005, vol. 9, no. 2, p. 302, 2008.

Al Qalam: Jurnal Ilmiah Keagamaan dan Kemasyarakatan Vol. 16, No. 1 Januari - Juni 2022 
Arizki Dwi Prasetyo, Kesadaran Santri Pondok Pesantren Al-Aqobah Dalam Menerapkan Protokol Kesehatan di Masa Pandemi Covid-19

Informan pertama bernama Syahrul, saat ini ia berusia 15 tahun. Mulai mengikuti kegiatan pembelajaran di pondok pesantren Al-Aqobah sejak kelas 1 SMP, artinya sekitar 3 tahun lamanya sudah menjadi santri pondok pesantren Al-Aqobah. Ia menjelaskan bahwa kegiatan diniyah sudah berjalan sejak bulan oktober kurang lebih sudah berjalan selama 5 bulan. Kegiatan pembelajaran yang dilaksanakan sudah berjalan normal seperti sebelumnya, tidak ada perbedaan sistem pemebalajran di masa pandemi dengan sebelumnya. Bagian yang membedakan kegiatan masjid di masa pandemi dengan sebelumnya hanyalah pada atribut yang digunakan, dimana di masa pandemi santri wajib menggunakan masker untuk dapat mengikuti kegiatan pembelajaran. Sedangkan saat sebelum masa pandemi tidak ada kewajiban untuk menggunakan masker seperti saat ini. Informan menjelaskan bahwa, saat ini masker menjadi salah satu syarat wajib untuk dapat mengikuti kegiatan pembelajaran masjid di masa pandemi. Sebagai salah satu bentuk melaksanakan protokol kesehatan yang dianjurkan pemerintah. Meskipun telah menggunakan masker selama berada di masjid, akan tetapi jaga jarak tidak di terapkan saat berada dalam kelas. Informan menjelaskan tidak ada jaga jarak yang ditentukan oleh masjid saat berada dalam kelas, jika ada jaga jarak itu tergantung pada individu masing-masing. Biasanya ada santri yang ingin jaga jarak dan ia memilih untuk menjauh dari teman-temannya. Dalam satu kelas diisi dengan 1520 santri. Kemudian, tidak ada pengurangan jumlah santri yang mengikuti kegiatan masjid di masa pandemi. Selama masa pandemi, kegiatan pembelajaran yang dilaksanakan tidak memiliki perbedaan yang sangat berarti dari sebelumnya. Namun, hal yang membedakan terletak pada sistem pembelajran di masa pandemi ini di percepat. Saat ini, santri pondok pesantren Al-Aqobah sedang melaksanakan ujian. Padahal baru saja masuk 3 bulan penuh. Kegiatan pembelajaran dipercepat karena mulai kegiatan yang telat dan waktu yang tersedia singkat, sehingga proses pembelajran di kebut untuk tuntas dalam satu semester. Terkait protokol kesehatan, yang dipahami oleh informan bahwa protokol kesehatan itu menggunakan masker atau face shield, mencuci tangan menggunakan sabun atau hand sanitizer, serta jaga jarak. Sedangkan, menurut informan menerapkan protokol kesehatan yang baik dan benar adalah yang sesuai dengan aturan yang telah ditetapkan oleh pemerintah. Kita sebagai manusia mengikuti apa yang telah dianjurkan agar dapat terhindar dari virus. Menjaga diri sendiri serta menyelamatkan orang lain. Protokol kesehatan berfungsi agar diri sendiri tidak terjangkit virus mematikan ini, atau sebagai pelindung diri agar tidak tertular dari orang lain.

Informan kedua bernama Lutfi, saat ini ia kelas 2 SMA berusia 17 tahun. Masuk dalam Pondok Pesantren Al-Aqobah Jombang sejak usia 13 tahun. Sampai saat ini ia masih menjadi bagian dari santri pondok pesantren Al-Aqobah. Mengikuti kegiatan pembelajaran pondok pesantren Al-Aqobah sejak usia 13 tahun hingga saat ini membuatnya jadi mengetahui bagaimana

Al Qalam: Jurnal Ilmiah Keagamaan dan Kemasyarakatan Vol. 16, No. 1 Januari - Juni 2022 
Arizki Dwi Prasetyo, Kesadaran Santri Pondok Pesantren Al-Aqobah Dalam Menerapkan Protokol Kesehatan di Masa Pandemi Covid-19

pembelajaran yang dilaksanakan dimasa pandemi dengan sebelum pandemi. Saat pandemi, kegiatan di pesantren berhenti untuk sementara. Sampai pada akhirnya, pada bulan september kegiatan berjalan kembali dengan syarat menjalankan kegiatan di masa pandemi. Sejak bulan september hingga saat ini kegiatan berjalan seperti biasanya, tidak ada perbedaan antara sebelum pandemi dengan saat pandemi. Namun, informan menjelaskan, kegiatan yang berjalan di masa pandemi kurang efektif. Menurutnya, di masa pandemi kegiatan dilaksanakan dengan mengurangi jumlah jam belajar, baik itu hari ataupun durasi waktu. Jika biasanya pertemuan dilaksanakan 5 kali dalam seminggu yaitu pada hari senin sampai jumat, di masa pandemi kegiatan dilaksanakan secara bergantian. Dalam satu minggu hanya ada 3 kali pertemuan. Selain itu, jam pembelajaran yang dikurangi juga menjadi kurang efektif dan efisien. Biasanya, kegiatan dilaksakan mulai jam 2 siang, namun di masa pandemi kegiatan hanya dilaknakan pada sore hari yaitu jam 4. Ia menambahkan, pengurangan jam tersebut membuat pelajaran yag di dapat menjadi sedikit, terlebih sistem pembelajaran yang dipercepat karena akan libur akhir tahun. Saat ini santri sedang melaknakan ujian, sedangkan pembelajaran baru saja dilaksanakan. Kemudian, selama masa pandemi syarat untuk mengikuti kegiatan pembelajaran di masjid adalah selalu menggunakan masker. Saat berada di dalam kelas, informan menjelaskan bahwa jaga jarak tetap diterapkan. Duduk di berdempet-dempetan, sehingga ada jarak yang memisahkan meskipun tidak mencapai batas minimum jaga jarak. Setidaknya ada jarak saat berada dalam kelas. Dalam satu kelas, diisi dengan 20 santri. Jika dilihat kelas tidak terlalu penuh dan tidak menyebabkan berkumpul tanpa jarak. Di masa pandemi jumlah santri dalam satu kelas tidak dikurangi, sama seperti biasanya. Terkait protokol kesehatan, informan menjelaskan protokol kesehatan yaitu mengikuti arahan pemerintah agar diri terjaga dari penyakit, melalui soscial distancing, tidak berdempet-dempetan, selalu menggunakan masker dimanapun berada, karena menjadi hal yang penting di masa pandemi untuk menjaga kesehatan diri. Sedangkan, menerapkan protokol kesehatan yang baik dan benar menurut informan dengan selalu menggunakan masker saat melakukan aktifitas diluar rumah, dan mengikuti anjuran pemerintah untuk melakukan social distancing.

Informan ketiga bernama Faiz, saat ini ia berusia 16 tahun dan kelas 1 SMA. Informan telah Masuk dalam Pondok Pesantren Al-Aqobah Jombang sejak usia 13 tahun. Secara tidak langsung ia telah mengetahui bagaimana kegiatan yang dilaksakan sebelum dan saat pandemi. Kegiatan pembelajaran di masjid mulai aktif kembali sejak bulan oktober. Awal pertemuan hingga saat ini kegiatan mulai berjalan aktif seperti biasanya, meskipun kegiatan dilaksanakan di masa pandemi. Bukan menjadi halangan untuk tidak dapat melakukan kegiatan di masa pandemi seperti saat ini. Selama masa pandemi, kegiatan berjalan dengan normal seperti biasanya. Namun yang berbeda adalah di masa pandemi saat berada di dalam kelas seluruh santri menggunakan

Al Qalam: Jurnal Ilmiah Keagamaan dan Kemasyarakatan Vol. 16, No. 1 Januari - Juni 2022 
Arizki Dwi Prasetyo, Kesadaran Santri Pondok Pesantren Al-Aqobah Dalam Menerapkan Protokol Kesehatan di Masa Pandemi Covid-19

masker tanpa terkecuali. Jika ada yang tidak menggunakan masker pihak yayasan akan memulangkan santri. Masker menjadi syarat khusus untuk mengikuti kegiatan pembelajaran masjid di masa pandemi, yang mana masker merupakan salah satu protokol kesehatan yang harus diterapkan saat menjalankan aktifitas di luar rumah. Saat berada dalam kelas, tidak ada jarak yang di atur untuk menerapkan protokol kesehatan. Jarak terbentuk dengan sendirinya saat menjalankan kegiatan di dalam kelas. Jumlah peserta dalam satu kelas tidak ada pengurangan, selama menjalankan kegiatan di masa pandemi sama dengan sebelum masa pandemi. Hal ini disiasati dengan pergantian jam masuk, sehingga jumlah dalam satu kelas tidak berkurang, yang berkurang hanya jumlah peserta dalam satu hari. Terkait protokol kesehatan, informan menjelaskan bahwa protokol kesehatan itu menggunakan masker saat beraktifitan diluar rumah, mencuci tangan menggunakan sabun, serta jaga jarak agar tidak tertular virus covid-19. Hal ini berkaitan dengan peraturan masjid yang mengharuskan semua memakai masker saat melakukan aktifitas di masjid. Jika ada santri yang tidak menggunakan masker maka tidak diizinkan untuk mengikuti kegiatan pembelajaran. Menerapkan protokol kesehatan yang baik dan benar menurut informan dengan selalu menggunakan masker, tidak lupa saat akan melakukan aktifitas diluar rumah. Selain itu, sesuai dengan apa yang telah di standarkan oleh pemerintah, sesuai dengan aturan protokol kesehatan di masa pandemi covid-19.

Informan keempat bernama Abdullah, saat ini informan berusia 17 tahun dan menjadi santri yang mengikuti kegiatan pesantren di masa pandemi. Ia menjelaskan, kegiatan mulai aktif sejak september. Sejak awal kegiatan mulai, ia melihat penerapan protokol kesehatan masih kurang. Saat awal masuk ia melihat ada santri yang tidak menggunakan masker. Namun, saat yayasan masjid memberikan peraturan bagi yang tidak menggunakan masker tidak boleh mengikuti kegiatan pesantren ia tidak lagi melihat santri yang tidak menggunakan masker. Sejak dimulai bulan september, kegiatan berjalan aktif selama 5 hari dalam 1 minggu. Selama masa pandemi, kegiatan pembelajaran wajib menggunakan masker. Hal ini tidak hanya berlaku pada santri, namun juga berlaku untuk guru, pihak yayasan, serta tamu yang melakukan aktivitas di lingkungan pesantren selama masa pandemi. Penggunaan masker menjadi peraturan yang wajib ditaati selama menjalankan kegiatan di masa pandemi. Saat berada di kelas, pihak yayasan tidak menerapkan jaga jarak antar santri. Jumlah santri yang tidak terlalu banyak dalam satu kelas membuat yayasan tidak menetapkan aturan harus jaga jarak saat di kelas. Selain itu, pihak yayasan juga tidak ada mengambil kebijakan untuk mengurangi jumlah santri satu kelas yang hadir dalam sehari, namun yayasan pondok pesantren Al-Aqobah mengubahnya dengan cara yang lain yang tetap sesuai dengan arahan protokol kesehatan. Selama menjalankan kegiatan pembelajaran di masa pandemi, perbedaan yang sangat terlihat saat berada dalam kelas. Tidak

Al Qalam: Jurnal Ilmiah Keagamaan dan Kemasyarakatan Vol. 16, No. 1 Januari - Juni 2022 
Arizki Dwi Prasetyo, Kesadaran Santri Pondok Pesantren Al-Aqobah Dalam Menerapkan Protokol Kesehatan di Masa Pandemi Covid-19

biasanya melihat menggunakan pakaian ngaji namun menggunakan masker dalam satu kelas. Kemudian, meskipun masker menjadi wajib saat menjalankan kegiatan di pesantren, masker juga menjadi hal yang menghalangi saat melaksanakan ngaji. Terutama saat membaca al-quran, suara yang terdengar menjadi kurang jelas, begitu informan menjelaskan. Menurut pemahaman informan, protokol kesehatan adalah sesuatu yang harus dilakukan demi keamanan dan kenyaman bersama seperti, menggunakan masker, mencuci tangan menggunakan sabun atau hand sanitizer, namun lebih lengkapnya lagi informan masih belum dapat menjelaskan dengan jelas. Jika ada santri yang tidak menggunakan masker akan mendapatkan teguran. Menerapkan protokol kesehatan yang baik dan benar menurutnya melakukan apa yang sesuai dengan peraturan pemerintah.

Informan kelima bernama Angga, ia berusia 18 tahun atau duduk di bangku Sekolah Menengah Atas. Ia mulai masuk dalam kegiatan pembelajaran pondok pesantren Al-Aqobah sejak umur 16 tahun. Sampai saat ini, ia masih aktif mengikuti kegiatan meskipun di masa pandemi. Sama seperti informan lain, ia menjelasakan bahwa kegiatan mulai aktif kembali pada bulan september setelah berhenti hampir 6 bulan. Sejak mulai kembali, kegiatan berjalan aktif seperti sebelum pandemi. Menurut informan, untuk dapat mengikuti kegiatan masjid yang dijalankan di masa pandemi wajib mentaati peraturan yang ditentukan oleh pihak yayasan pesantren, yaitu selalu menggunakan masker. Kegiatan pembelajaran di masa pandemi berbeda dengan biasanya, yang mana saat pandemi ada syarat tambahan untuk selalu menggunakan masker. Bahkan, masker menjadi hal yang wajib ditaati oleh seluruh orang yang melakukan aktifitas di pesantren selama masa pandemi. Saat berada dalam kelas, santri juga diwajibkan untuk tetap menggunakan masker. Namun, jaga jarak saat berada di dalam kelas tidak di tetapkan oleh guru atau yayasan, sehingga santri bebas ingin duduk secara berjarak jauh atau biasa. Biasanya santri akan otomatis berjarak dengan sendirinya, sesuai dengan kesadaran masing-masing tanpa perlu di berikan ketentuan atau arahan khusus. Saat kegiatan berlangsung di masa pandemi, tidak ada pengurangan jumlah peserta dalam satu kelas agar tidak terjadi penumpukan orang. Karena jumlah peserta yang memang sedikit, maka pihak yayasan tidak mengurangi jumlah santri dalam satu kelas tetap sesuai dengan sebelumnya. Terkait protokol kesehatan, informan menjelaskan bahwa menggunakan masker atau face shield, mencuci tangan menggunakan sabun atau hand sanitizer, serta menerapakan jaga jarak merupakan salah satu bentuk pengertian dari protokol kesehatan. Sedangkan, menerapkan protokol kesehatan yang baik dan benar menurutnya dengan menggunakan masker saat akan keluar rumah terutama saat melakukan kegiatan di pesantren, karena masker ini berfungsi sebagai pelindung diri agar tidak tertular virus covid-19. Ia juga menambahkan bahwa virus corona ini

Al Qalam: Jurnal Ilmiah Keagamaan dan Kemasyarakatan Vol. 16, No. 1 Januari - Juni 2022 
Arizki Dwi Prasetyo, Kesadaran Santri Pondok Pesantren Al-Aqobah Dalam Menerapkan Protokol Kesehatan di Masa Pandemi Covid-19

merupakan virus yang tidak dapat dilihat oleh mata, sehingga perlu adanya pencegahan dengan menggunakan masker serta mencuci tangan sesuai dengan aturan yang telah di tetapkan.

Kesadaran Santri Pondok Pesantren Al-Aqobah Tentang Protokol Kesehatan di Masa Pandemi Covid-19 dengan menggunakan kajian teori interaksi simbolik Blumer yang pokok perhatian interaksionisme simbolis mengacu pada dampak makna dan symbol terhadap tindakan dan interaksi manusia. Dari data yang diperoleh maka analisisnya ialah, kegiatan pondok pesantren sudah berjalan sejak bulan september setelah sebelumnya berhenti hampir 3 bulan karena pandemi. Akan tetapi, kegiatan pondok pesantren kembali aktif meskipun pandemi belum berakhir. Kegiatan yang berjalan di masa pandemi tidak ada perbedaan dengan sebelumnya. Hanya ada pengurangan jam belajar dan hari masuk yang tidak full senin sampai jumat. Saat pandemi, kegiatan dijalankan dengan peraturan masjid untuk menerapkan protokol kesehatan seperti, menggunakan masker, mencuci tangan menggunakan sabun, menggunakan hand sanitizer, dan jaga jarak. Jika ada santri yang tidak menggunakan masker, pihak yayasan tidak mengizinkan santri tersebut untuk mengikuti kegiatan pembelajaran. Kemudian, sebelum melaksanakan kegiatan di dalam kelas santri mencuci tangan dengan sabun yang telah di sediakan wastafel di area lingkungan pondok pesantren. Kesadaran santri dalam menerapkan protokol kesehatan saat menjalankan kegiatan di masa pandemi dibangun dengan peraturan yang ditetapkan oleh pengurus pondok pesantren. Selain itu, setiap hari jumat kepala yayasan atau pengasuh memberikan sosialisasi tentang protokol kesehatan pada santri yang mengikuti kegiatan pembelajaran di masa pandemi. Serta, orang tua dan masyarakat sekitar yang selalu mengingatkan santri yang mengikuti kegiatan pembelajaran untuk selalu menggunakan masker saat melakukan kegiatan pembelajaran. Santri telah memahami apa yang dimaksud dengan protokol kesehatan, yang harus diterapkan saat melakukan aktifitas di tengah pendemi. Sehingga, kesadaran santri terkait protokol kesehatan dalam menjalankan kegiatan pembelajaran sudah baik.

\section{KESIMPULAN}

Kesimpulan dari penelitian ini yaitu, kesadaran santri dalam menerapkan protokol kesehatan saat menjalankan kegiatan pembelajaran di masa pandemi sudah baik. Artinya, santri telah memahami apa yang dimaksud dengan protokol kesehatan serta menerapkannya, sadar akan pentingnya menerapkan protokol kesehatan saat menjalankan kegiatan pesantren di masa pandemi. Ada 3 tahapan pembentukan kesadaran santri tentang protokol kesehatan. Pertama, pihak yayasan memberikan peraturan dan sosialisasi agar santri memahami tentang protokol kesehatan yang sesuai. Kedua, orang tua berperan untuk mengingatkan santri untuk selalu menerapkan protokol kesehatan saat akan melaksanakan kegiatan pembelajaran di masa pandemi.

Al Qalam: Jurnal Ilmiah Keagamaan dan Kemasyarakatan Vol. 16, No. 1 Januari - Juni 2022 
Arizki Dwi Prasetyo, Kesadaran Santri Pondok Pesantren Al-Aqobah Dalam Menerapkan Protokol Kesehatan di Masa Pandemi Covid-19

Ketiga, masyarakat sekitar yang memberikan teguran pada santri ketika tidak menerapkan protokol kesehatan yang sesuai.

\section{DAFTAR PUSTAKA}

Aulia, K. N. (2020). Meningkatkan Kesadaran Masyarakat Untuk Memperhatikan Prokes (Protokol Kesehatan) Dalam Beraktifitan di Era NeNo (New Normal) dengan Media PEPC (Poster Edukasi Pencegahan Covid-19) Melalui Media Wafagram (WA, Facebook, dan Instagram) di Kampung Padang Lab. Universitas Negeri Padang, 1-23.

Froming, W. J., \& Carver, C. S. (1981). Divergent influences of private and public selfconsciousness in a compliance paradigm. Journal of Research in Personality, 15(2), 159171. https://doi.org/10.1016/0092-6566(81)90015-5

Hasbiansyah, O. (2008). Pendekatan Fenomenologi: Pengantar Praktik Penelitian dalam Ilmu Sosial dan Komunikasi. Mediator: Jurnal Komunikasi, 9(1), 163-180. https://doi.org/10.29313/mediator.v9i1.1146

Huang, Y. W., Lin, P. C., \& Wang, J. (2018). The influence of bus and taxi drivers' public selfconsciousness and social anxiety on aberrant driving behaviors. Accident Analysis and Prevention, 117(May 2017), 145-153. https://doi.org/10.1016/j.aap.2018.04.014

Satria, A. B. A. (2020). Pelaksanaan Ibadah Salat Berjamaah Dalam Masa Pandemi Covid-19 Di Kelurahan Kalicacing Kecamatan Sidomukti Kota Salatiga Tahun 2020.9.

F. C. Farisa, "Presiden Jokowi: Saat Ini Semua Wajib Pakai Masker," Kompas.com, 2021. https://nasional.kompas.com/read/2021/07/19/05312271/presiden-jokowi-saat-ini-semuawajib-pakai-masker.

D. Z. R. Syah, D. Utari, and ..., "Edukasi penerapan protokol kesehatan penyelenggaraan kegiatan pada masa pandemi Covid 19 Di TPQ Masjid Awalulmu'Minin," J. Pengabdi. ..., vol. 2, no. 2, pp. 28-33, 2020, [Online]. Available: http://jurnal.poltekkeskhjogja.ac.id/index.php/jpmkh/article/view/408.

D. Ahmadi, "INTERAKSI SIMBOLIK: SUATU PENGANTAR," Terakreditasi Dirjen Dikti SK No. 56/DIKTI/Kep/2005, vol. 9, no. 2, p. 302, 2008.

Al Qalam: Jurnal Ilmiah Keagamaan dan Kemasyarakatan Vol. 16, No. 1 Januari - Juni 2022 